\title{
Novel One-Tube-One-Step Real-Time Methodology for Rapid Transcriptomic Biomarker Detection: Signal Amplification by Ternary Initiation Complexes
}

Hiroto Fujita ${ }^{1}$, Yuka Kataoka ${ }^{1}$, Seiji $_{\text {Tobita }}{ }^{1}$, Masayasu Kuwahara*,1, and Naoki Sugimoto ${ }^{2,3}$

${ }^{1}$ Graduate School of Science and Technology, Gunma University, 1-5-1 Tenjin-cho, Kiryu, Gunma 3768515, Japan

${ }^{2}$ Frontier Institute for Biomolecular Engineering Research (FIBER) and ${ }^{3}$ Faculty of Frontiers of Innovative Research in Science and Technology (FIRST), Konan University, 7-1-20 MinatojimaMinamimachi, Kobe 650-0047, Japan

*To whom correspondence should be addressed. E-mail: mkuwa@gunma-u.ac.jp, Phone/Fax: +81-277$30-1222$. 


\section{EXPERIMENTAL DETAILS}

The SATIC system for miRNA detection. Target or non-target RNA (miR-21 or miR-221; $10 \mathrm{nM}, 2 \mu \mathrm{L}$ ) was added to a mixture $(18 \mu \mathrm{L})$ that comprises primer $\mathrm{P}_{2}(480 \mathrm{nM}, 2 \mu \mathrm{L})$, circular DNA template $\mathrm{cT}_{1} \mathrm{C}$ (100 nM, $2 \mu \mathrm{L})$, circular DNA template $\mathrm{cT}_{2}(400 \mathrm{nM}, 2 \mu \mathrm{L})$, dNTP mix (dATP, dCTP, dGTP, and TTP; 10 mM each, $2 \mu \mathrm{L}), \varphi 29$ DNA polymerase $(1 \mathrm{U} / \mu \mathrm{L}, 2 \mu \mathrm{L}), 10 \times \varphi 29$ buffer $(2 \mu \mathrm{L})$, BSA solution $(10 \mathrm{mg} / \mathrm{mL}$, $0.2 \mu \mathrm{L})$, and ultrapure water $(5.8 \mu \mathrm{L})$. The each reaction mixture $(20 \mu \mathrm{L})$ was incubated at $37^{\circ} \mathrm{C}$ for 2 hours, subsequently quenched with $5 \times \operatorname{PBS}(5 \mu \mathrm{L})$, divided into two portions (10 $\mu \mathrm{L}$ each), to which $2 \mu \mathrm{L}$ of a dye solution in $1 \times$ PBS, i.e., ThT-HE $(30 \mu \mathrm{M})$ or SYBR Gold (12.5× concentration), was added, respectively, and incubated at room temperature for $30 \mathrm{~min}$. Then, photographs were captured in the same way as described above (Figure S7).

Correlation line and limit of detection (LOD). The real-time quantitative analysis of the target RNA CidR at 13 different concentrations was conducted using a CFX96 real-time PCR detection system (Figure S8). Respective relative rates of reaction (A) were obtained by fitting the time course data of fluorescence intensity from 0 to 100 min with equation 1 , where $\mathrm{I}$ is the fluorescence intensity, $t$ is the reaction time, A is the relative rate of reaction, and $\mathrm{B}$ is the $\mathrm{y}$-intercept.

$$
\mathrm{I}=\mathrm{A} t+\mathrm{B} \quad e q \cdot 1
$$

Three independent measurements $(n=3)$ were performed at a single concentration for all A value determinations. Standard deviations $(m)$ were calculated using equation 2 , where $\overline{\mathrm{A}}$ is the average of those measurements ( $\mathrm{A}_{1}, \mathrm{~A}_{2}$, and $\left.\mathrm{A}_{3}\right)$.

$$
m=\sqrt{\frac{\left(\mathrm{A}_{1}-\overline{\mathrm{A}}\right)^{2}+\left(\mathrm{A}_{2}-\overline{\mathrm{A}}\right)^{2}+\cdots+\left(\mathrm{A}_{\mathrm{n}}-\overline{\mathrm{A}}\right)^{2}}{\mathrm{n}}} \quad \text { eq. } 2
$$


The squared $\bar{A}$ values (i.e., $\bar{A}^{2}$ ) with error bars, which show the standard deviations $(\sigma)$, were plotted versus target RNA concentrations, as shown in Figure 7. The standard deviations $(\sigma)$ were calculated using equation 3 .

$$
\sigma=\sqrt{2 \overline{\mathrm{A}}^{2} \cdot m^{2}} \quad \text { eq. } 3
$$

The correlation line as equation 4 could be plotted with a high correlation coefficient $\left(R^{2}=0.9998\right)$.

$$
y=0.3885 x \quad \text { eq. } 4
$$

Accordingly, the squared $\overline{\mathrm{A}}$ value with the standard deviation $(\sigma)\left(1.444 \times 10^{-4} \pm 1.426 \times 10^{-4}\right)$ in the absence of the target RNA provides an LOD of approximately $1.5 \mathrm{fM}$ wherein LOD is defined as $3 \sigma$ of the blank. Thus, it can be said that the present system achieves a detection limit of ca. $1 \mathrm{pM}$ at the highest estimate because the target RNA concentration of $1 \mathrm{pM}$ is the lowest in the examined concentrations. Indeed, the present system provides signal intensities with small $\sigma$ values, even in the low target concentrations; $\overline{\mathrm{A}}^{2} \pm \sigma$ equal to $1.166 \pm 0.072$ and $1.584 \pm 0.070$ at target concentrations of 1 and $5 \mathrm{pM}$, respectively (Table S2). 
Table S1. ODNs used in this study.

\begin{tabular}{|c|c|c|}
\hline ODN & 5'-Modification & Sequence $^{a}$ \\
\hline L1 & Non & AGCTCCTTTTTGGGGAGGGTGGGGAGGGTG \\
\hline L2 & Non & AGCTCCTTTTTGGGGACTTTTCTTCTTCGA \\
\hline L3 & Non & GTGGGTAGGGTTGGGAATTTTTTTTCTTCT \\
\hline $\mathrm{T}_{1} \mathrm{~A}$ & Phosphate & CCCCAAAAAGGAGCTTGAGGTTCTCCTTTAAAACCTTCCCCACССТCСCСАСССТ \\
\hline $\mathrm{T}_{1} \mathrm{~B}$ & Phosphate & CCCCAAAAAGGAGCTTGAGGTTCTCCTTTAAAAAGAAGCTGTTGTATTGTTGTCGAAGAAGAAAAGT \\
\hline $\mathrm{T}_{1} \mathrm{C}$ & Phosphate & CCCCAAAAAGGAGCTCAACATCAGTCTGATAAGCTAAAAAGAAGCTGTTGTATTGTTGTCGAAGAAGAAAAGT \\
\hline $\mathrm{T}_{2}$ & Phosphate & СССАACССТАСССАСССТCAAGAAAAAAAAGTGATAATTGTTGTCGAAGAAGAAAAAAAATT \\
\hline $\mathrm{P}_{0} \mathrm{~A}$ & Non & GGAAGGTTTTAAAGGAGAAC \\
\hline $\mathrm{P}_{0} \mathrm{~B}$ & Non & АACСTCAAGCTCСТTTTTGG \\
\hline $\mathrm{P}_{1}(16)$ & Non & GGATCAGGCCATTTTT \\
\hline $\mathrm{P}_{1}(17)$ & Non & GGATCAGGCCATTTTTG \\
\hline $\mathrm{P}_{1}(18)$ & Non & GGATCAGGCCATTTTTGG \\
\hline $\mathrm{P}_{1}(19)$ & Non & GGATCAGGCCATTTTTGGG \\
\hline $\mathrm{P}_{1}(20)$ & Non & GGATCAGGCCATTTTTGGGG \\
\hline $\mathrm{P}_{1}(16) \mathrm{b}$ & Biotin & GGATCAGGCCATTTTT \\
\hline $\mathrm{P}_{1}(17) \mathrm{b}$ & Biotin & GGATCAGGCCATTTTTG \\
\hline $\mathrm{P}_{1}(18) \mathrm{b}$ & Biotin & GGATCAGGCCATTTTTGG \\
\hline $\mathrm{P}_{1}(19) \mathrm{b}$ & Biotin & GGATCAGGCCATTTTTGGG \\
\hline $\mathrm{P}_{1}(20) \mathrm{b}$ & Biotin & GGATCAGGCCATTTTTGGGG \\
\hline $\mathrm{P}_{2}$ & Non & GAAGCTGTTGTTATCACT \\
\hline CidR & Non & GGGUUGGCCAAAGGAGAACCUCAAGCUCCUGGCCUGAUCC \\
\hline ArfR & Non & GGCCUGGAGGAGGUCUUUGGCAGGUCCCCUCUCGGGAAA \\
\hline miR-21 & Non & UAGCUUAUCAGACUGAUGUUGA \\
\hline miR-221 & Non & AgCUACAUUGUCUGCUGGGUUUC \\
\hline
\end{tabular}

${ }^{a}$ Sequences are aligned in the $5^{\prime}$ to $3^{\prime}$ direction. 
Table S2. Averaged relative rates of reaction $(\overline{\mathrm{A}})$, squared $\overline{\mathrm{A}}$ values $\left(\overline{\mathrm{A}}^{2}\right)$ and standard deviations $(m$ and $\sigma)$ obtained from the real-time quantitative analysis

\begin{tabular}{rrrrr}
\hline Target RNA concentration $(\mathrm{pM})$ & $\overline{\mathrm{A}}$ & $\pm m$ & $\overline{\mathrm{A}}^{2}$ & $\pm \sigma$ \\
0 & 0.01202 & 0.00839 & 0.0001444 & 0.0001426 \\
1 & 1.080 & 0.047 & 1.166 & 0.072 \\
5 & 1.258 & 0.039 & 1.584 & 0.070 \\
10 & 1.816 & 0.038 & 3.299 & 0.098 \\
50 & 4.329 & 0.086 & 18.74 & 0.53 \\
75 & 5.541 & 0.081 & 30.70 & 0.64 \\
100 & 5.878 & 0.272 & 34.55 & 2.26 \\
250 & 9.614 & 0.303 & 92.42 & 4.12 \\
500 & 13.98 & 0.18 & 195.4 & 3.6 \\
750 & 17.05 & 0.59 & 290.7 & 14.3 \\
1,000 & 20.00 & 0.90 & 399.9 & 25.3 \\
5,000 & 30.75 & 1.12 & 945.7 & 1953 \\
\hline
\end{tabular}


(A)

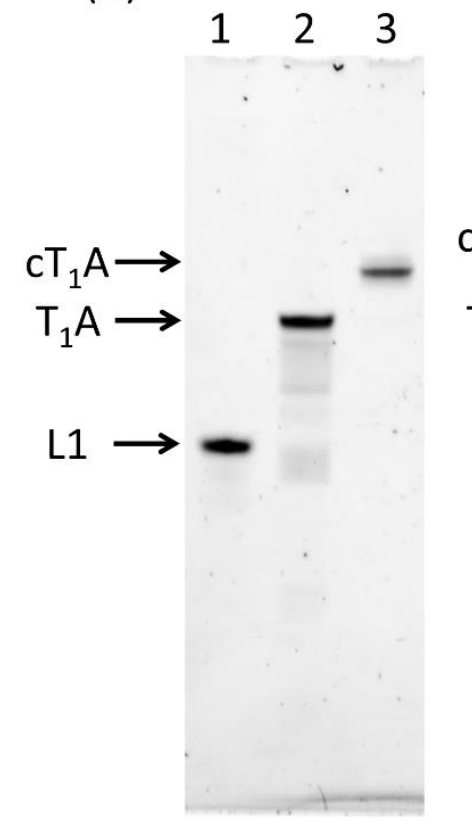

(B)

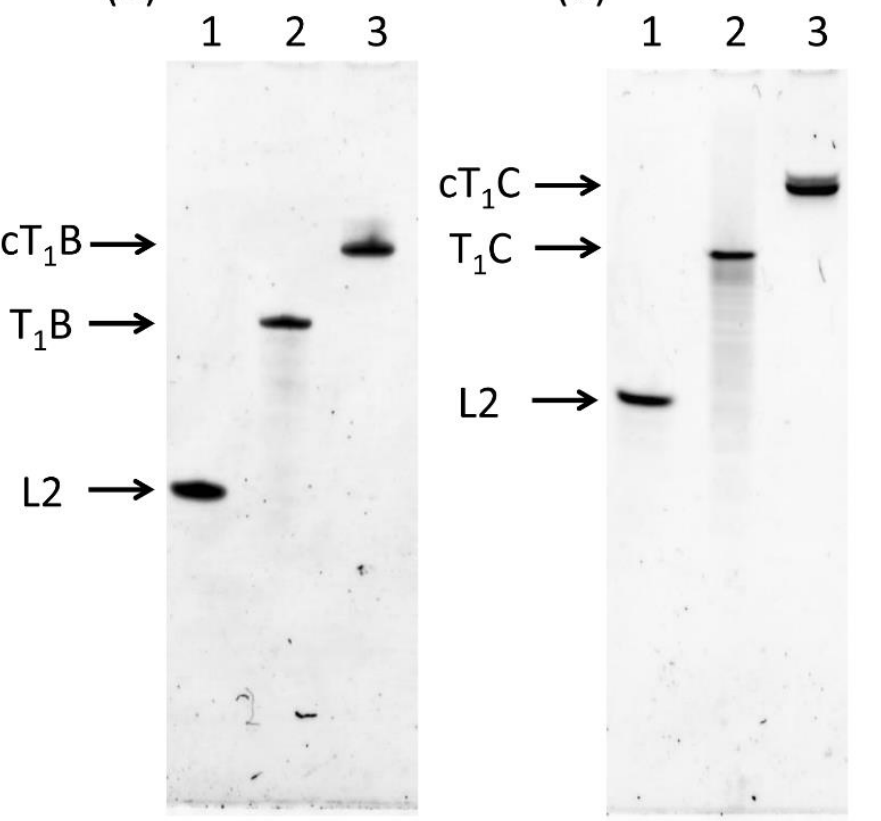

(C)

(D) 123

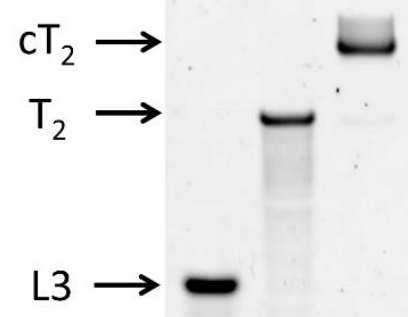

Figure S1. Preparations of circular DNA templates, (A) $\mathrm{cT}_{1} \mathrm{~A},(\mathrm{~B}) \mathrm{cT}_{1} \mathrm{~B},(\mathrm{C}) \mathrm{cT}_{1} \mathrm{C}$, and (D) $\mathrm{cT}_{2}$ by intramolecular ligation, i.e., circularization, of linear single-stranded DNAs (ssDNAs), $\mathrm{T}_{1} \mathrm{~A}, \mathrm{~T}_{1} \mathrm{~B}, \mathrm{~T}_{1} \mathrm{C}$, and $T_{2}$, respectively; short DNA fragments hybridized with linear ssDNAs in circularization (lane 1), linear ssDNAs (lane 2), and circular DNA templates purified by PAGE (lane 3). 
(A)

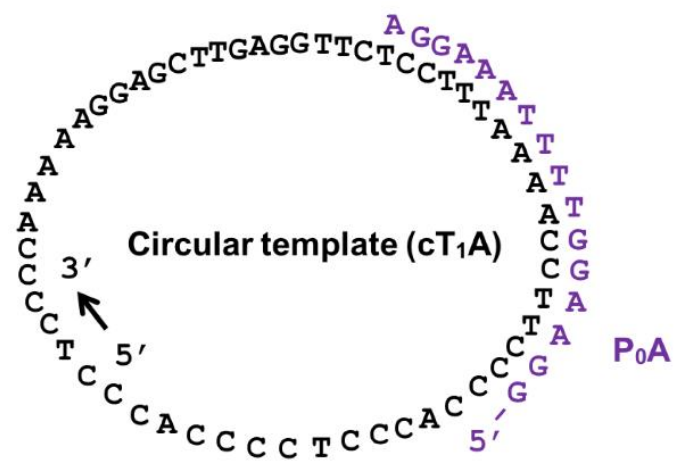

(C)

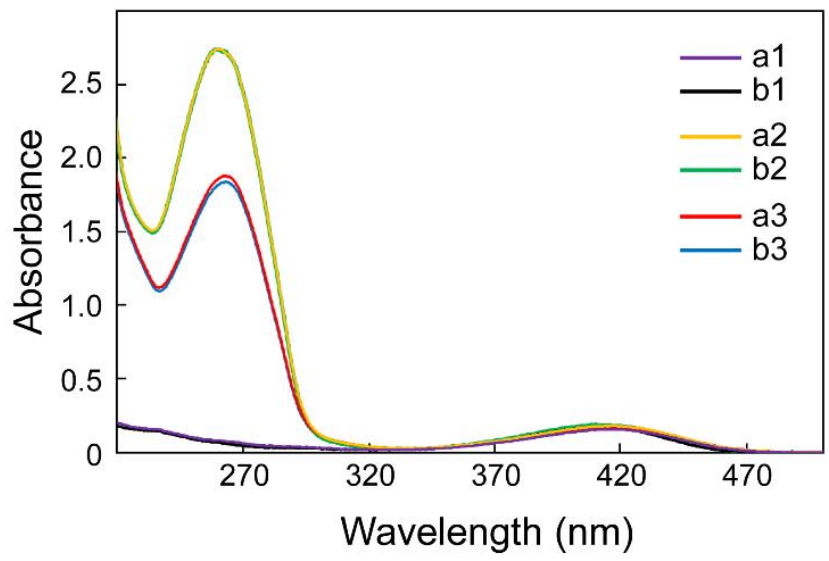

(B)

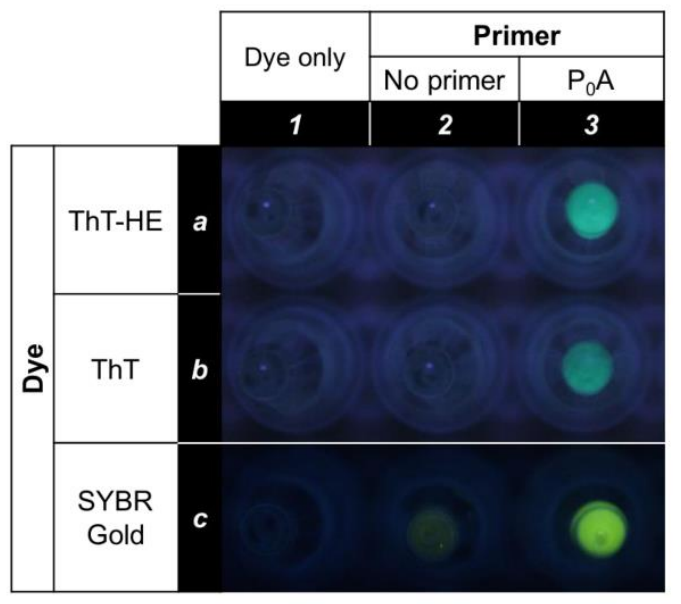

(D)

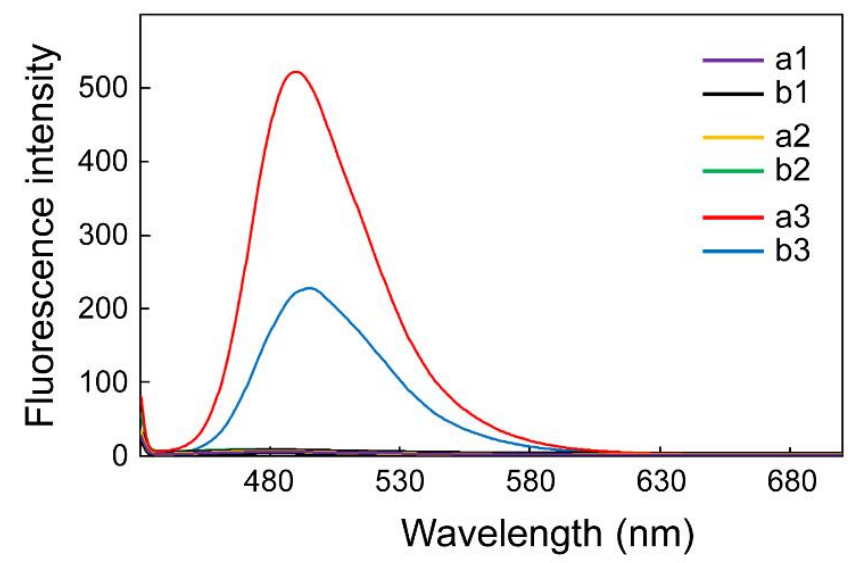

Figure S2. RCA production of G4 strings and their fluorescent staining: (A) sequences of primer ( $\left.\mathrm{P}_{0} \mathrm{~A}\right)$ and template $\left(\mathrm{cT}_{1} \mathrm{~A}\right)$ for the RCA reaction, $(\mathrm{B})$ a photograph of the aliquots in rows $\mathrm{a}$ and $\mathrm{b}$ containing ThT-HE and ThT, respectively, which was captured under visible light irradiation at $410 \mathrm{~nm}$, and a photograph of the aliquots in row c containing SYBR ${ }^{\circledR}$ Gold, which was captured under UV irradiation at $254 \mathrm{~nm}$. The aliquots in columns 1,2, and 3 are solutions containing the dye only, reaction mixtures without $\mathrm{P}_{0} \mathrm{~A}$, and with $\mathrm{P}_{0} \mathrm{~A}$, respectively. (C) UV-vis absorption spectra of the abovementioned six aliquots containing ThT-HE or ThT; (D) fluorescence spectra of the abovementioned six aliquots containing ThTHE or ThT. 


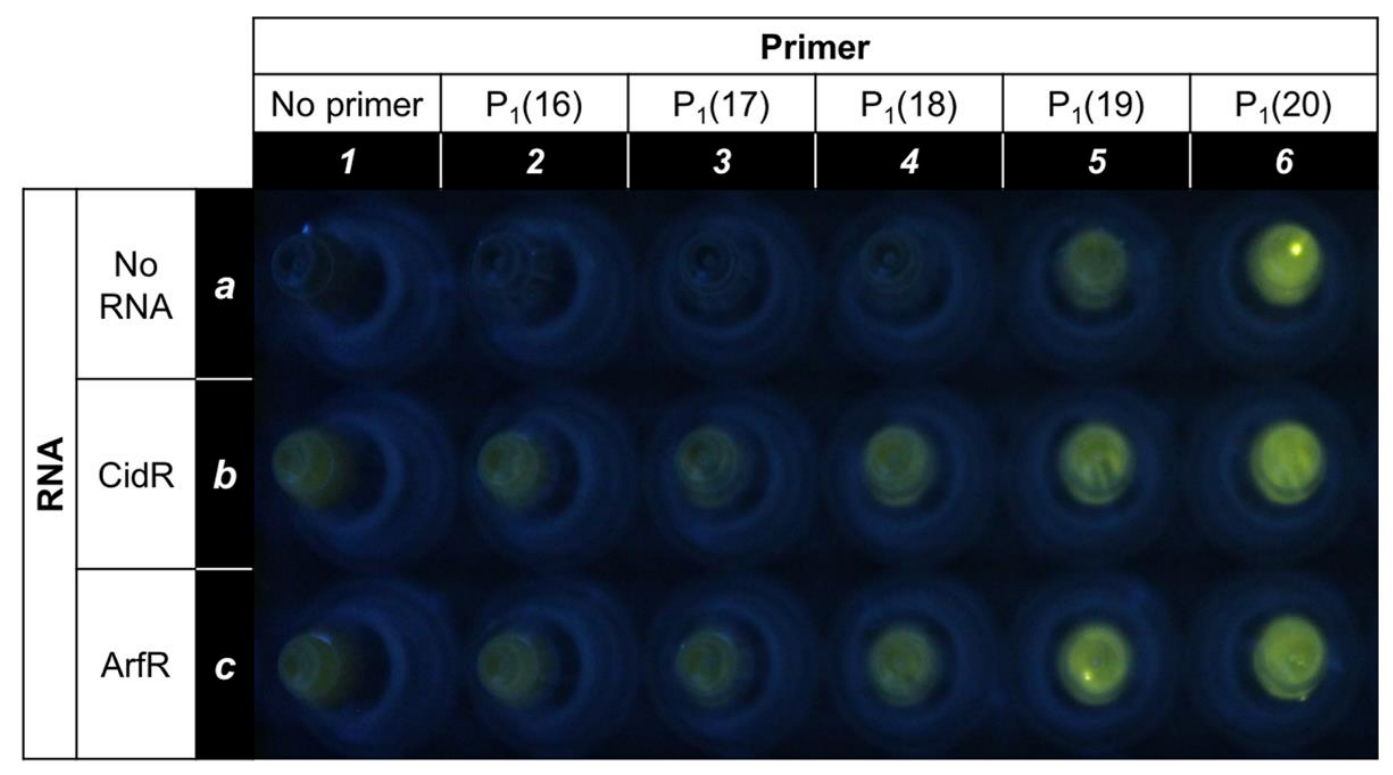

Figure S3. Determination of optimal primer length(s): a photograph of aliquots containing SYBR ${ }^{\circledR}$ Gold, which was captured under UV irradiation at $254 \mathrm{~nm}$. The aliquots in rows a, b, and c are reaction mixtures without RNA, with the target RNA (CidR), and with the non-target RNA (ArfR), respectively. Similarly, the aliquots in columns $1,2,3,4,5$, and 6 contain no primer, $P_{1}(16), P_{1}(17), P_{1}(18), P_{1}(19)$, and $P_{1}(20)$, respectively. 


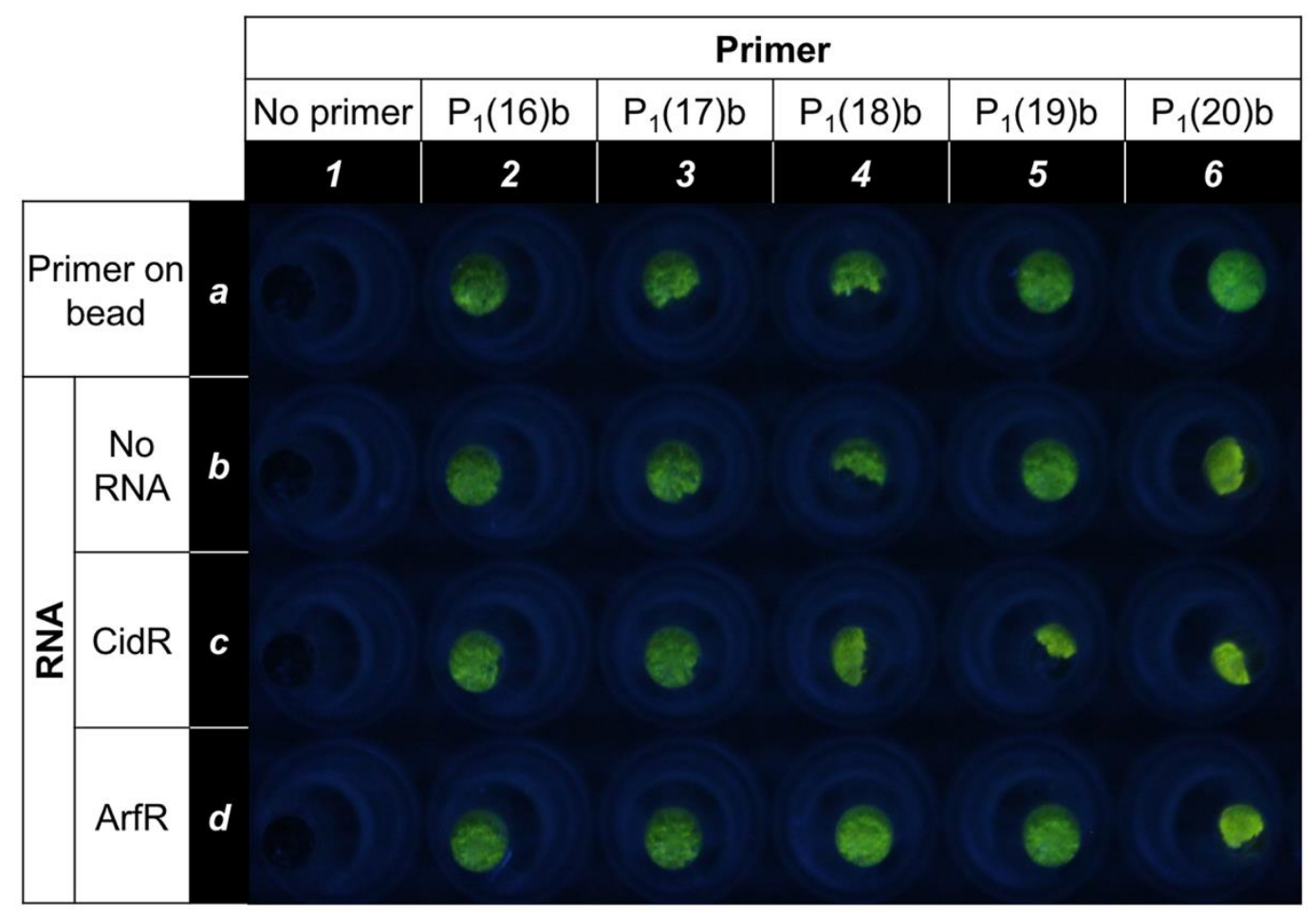

Figure S4. On-bead SATIC system: a photograph of the aliquots containing SYBR ${ }^{\circledR}$ Gold, which was captured under UV irradiation at $254 \mathrm{~nm}$. The aliquots in rows a, b, c, and d are solutions that contain beads bearing primers, reaction mixtures without RNA, with the target RNA (CidR), and with the nontarget RNA (ArfR), respectively. Similarly, the aliquots in the columns labeled 1, 2, 3, 4, 5, and 6 contain no primer, $\mathrm{P}_{1}(16) b, \mathrm{P}_{1}(17) b, \mathrm{P}_{1}(18) b, \mathrm{P}_{1}(19) b$, and $\mathrm{P}_{1}(20) b$, respectively. 


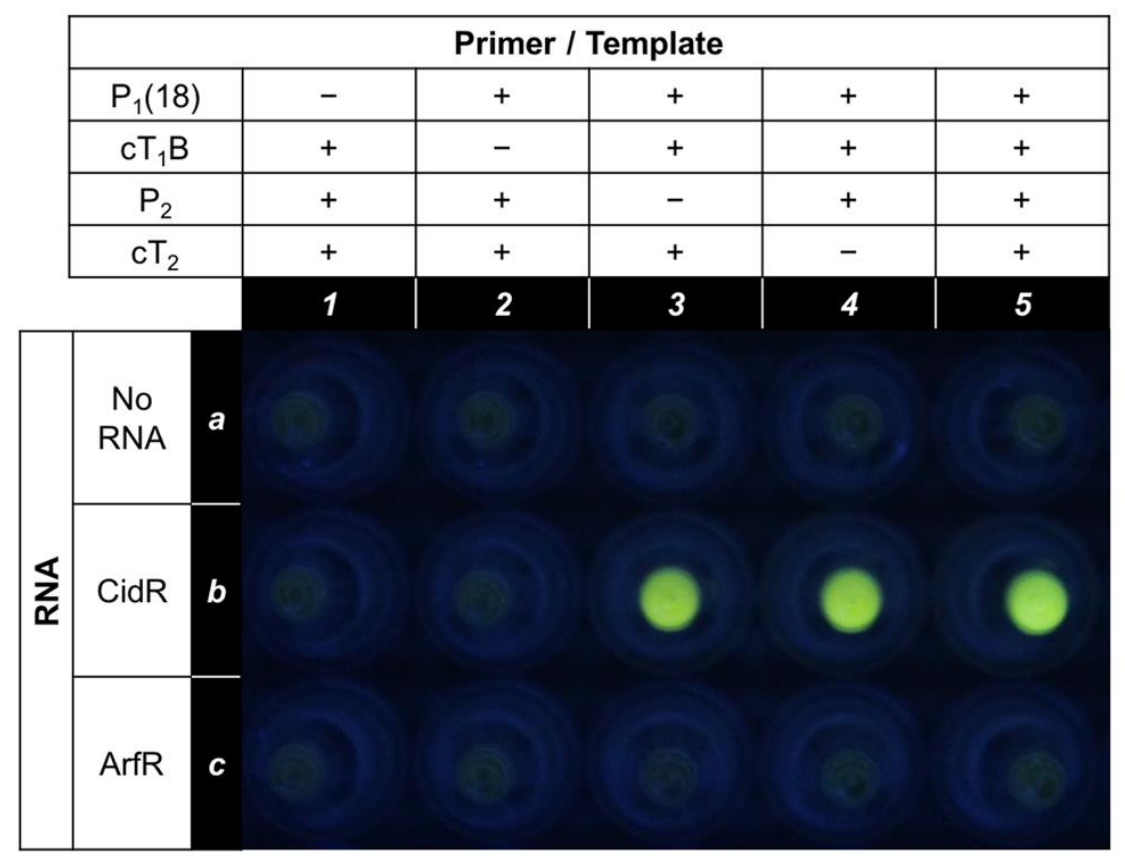

Figure S5. Dual SATIC system: a photograph of the aliquots containing SYBR ${ }^{\circledR}$ Gold, which was captured under UV irradiation at $254 \mathrm{~nm}$. The aliquots in rows $\mathrm{a}, \mathrm{b}$, and c are reaction mixtures without RNA, with the target RNA (CidR), and with the non-target RNA (ArfR), respectively. Similarly, the aliquots in columns 1, 2, 3, 4, and 5 contain components consisting of primer(s) and template(s) as described, where + and - indicate presence and absence, respectively. 
(A)

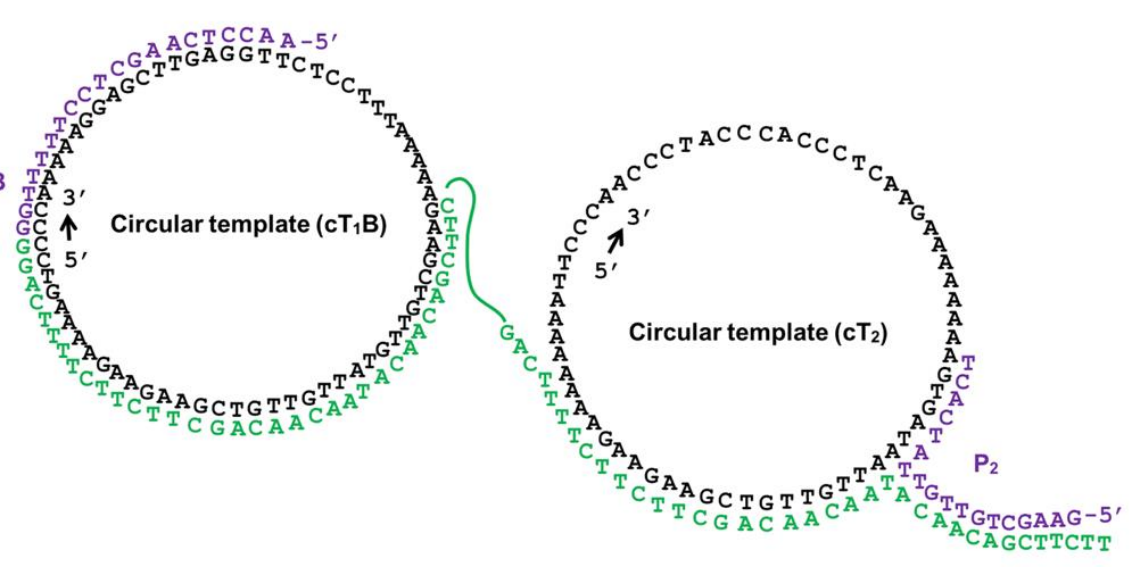

(B)

\begin{tabular}{|c|c|c|c|c|c|}
\hline Components & a1 & a2 & a3 & a4 & a5 \\
\hline CidR & - & - & - & - & + \\
\hline $\mathrm{P}_{1}(18)$ & - & + & + & - & + \\
\hline $\mathrm{P}_{0} \mathrm{~B}$ & - & - & - & + & - \\
\hline $\mathrm{cT}_{1} \mathrm{~B}$ & + & + & + & + & + \\
\hline $\mathrm{P}_{2}$ & - & - & - & - & - \\
\hline $\mathrm{CT}_{2}$ & - & - & + & + & + \\
\hline
\end{tabular}

\begin{tabular}{|c|c|c|c|c|c|}
\hline Tube & b1 & b2 & b3 & b4 & b5 \\
\hline CidR & + & + & + & - & + \\
\hline $\mathrm{P}_{1}(18)$ & - & - & - & - & + \\
\hline $\mathrm{P}_{0} \mathrm{~B}$ & - & - & - & + & - \\
\hline $\mathrm{cT}_{1} \mathrm{~B}$ & - & - & + & + & + \\
\hline $\mathrm{P}_{2}$ & - & + & + & + & + \\
\hline $\mathrm{cT}_{2}$ & + & + & + & + & + \\
\hline
\end{tabular}

(C)

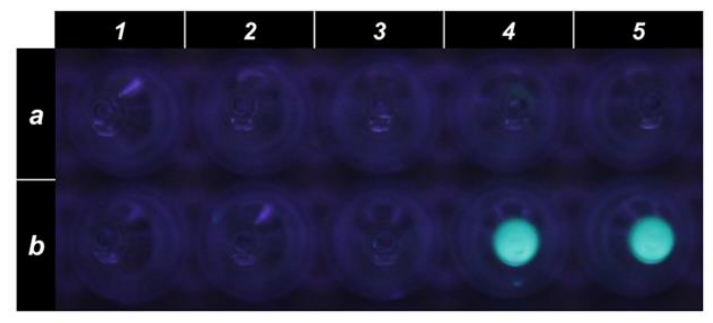

(D)

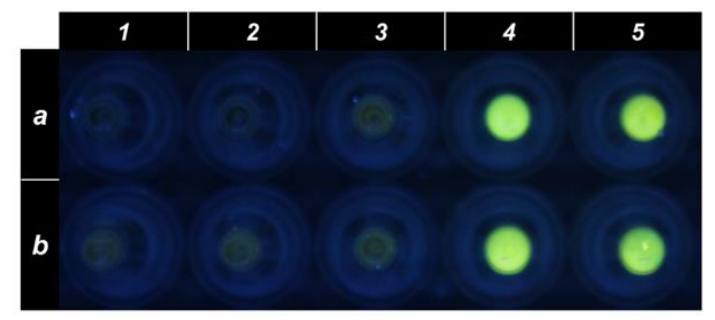

Figure S6. Control reactions for the dual SATIC system: (A) an example of the control reactions in tube b4 using primers $\left(\mathrm{P}_{0} \mathrm{~B}\right.$ and $\left.\mathrm{P}_{2}\right)$ and templates $\left(\mathrm{cT}_{1} \mathrm{~B}\right.$ and $\left.\mathrm{cT}_{2}\right)$; $(\mathrm{B})$ components of the ten reaction mixtures in tubes a1 to $\mathrm{a} 5$ and $\mathrm{b} 1$ to $\mathrm{b} 5$, where + and - indicate presence and absence, respectively; (C) a photograph of the aliquots containing ThT-HE, which was captured under visible light irradiation at $410 \mathrm{~nm}$; (D) a photograph of the aliquots containing SYBR ${ }^{\circledR}$ Gold, which was captured under UV irradiation at $254 \mathrm{~nm}$. 
(A)

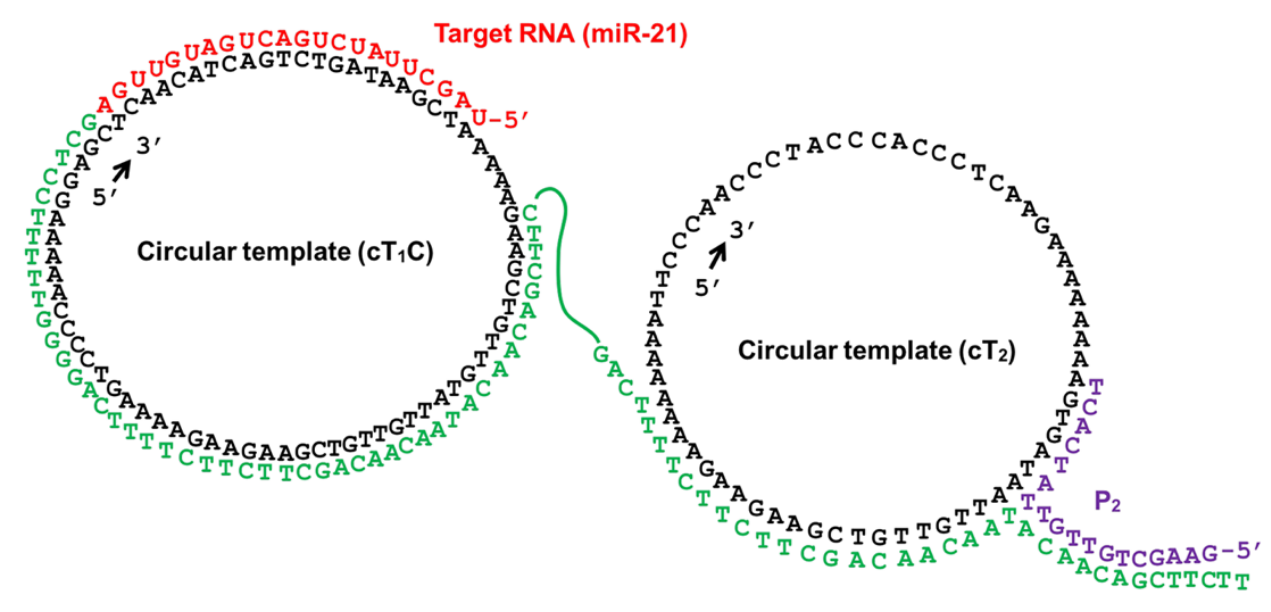

(B)

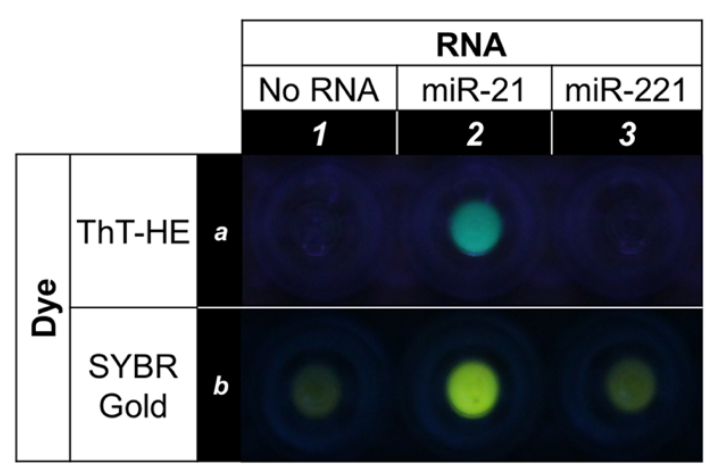

Figure S7. The SATIC system for miRNA detection: (A) sequences of the target RNA (miR-21), primer $\left(\mathrm{P}_{2}\right)$, and templates $\left(\mathrm{cT}_{1} \mathrm{C}\right.$ and $\left.\mathrm{cT}_{2}\right)$ for the miRNA detection reaction; (B) a photograph of the aliquots in row a containing ThT-HE, which was captured under visible light irradiation at $410 \mathrm{~nm}$, and a photograph of the aliquots in row b containing SYBR ${ }^{\circledR}$ Gold, which was captured under UV irradiation at $254 \mathrm{~nm}$. The aliquots in columns labeled 1, 2, and 3 are reaction mixtures without RNA, with the target RNA (miR21), and with the non-target RNA (miR-221), respectively. 


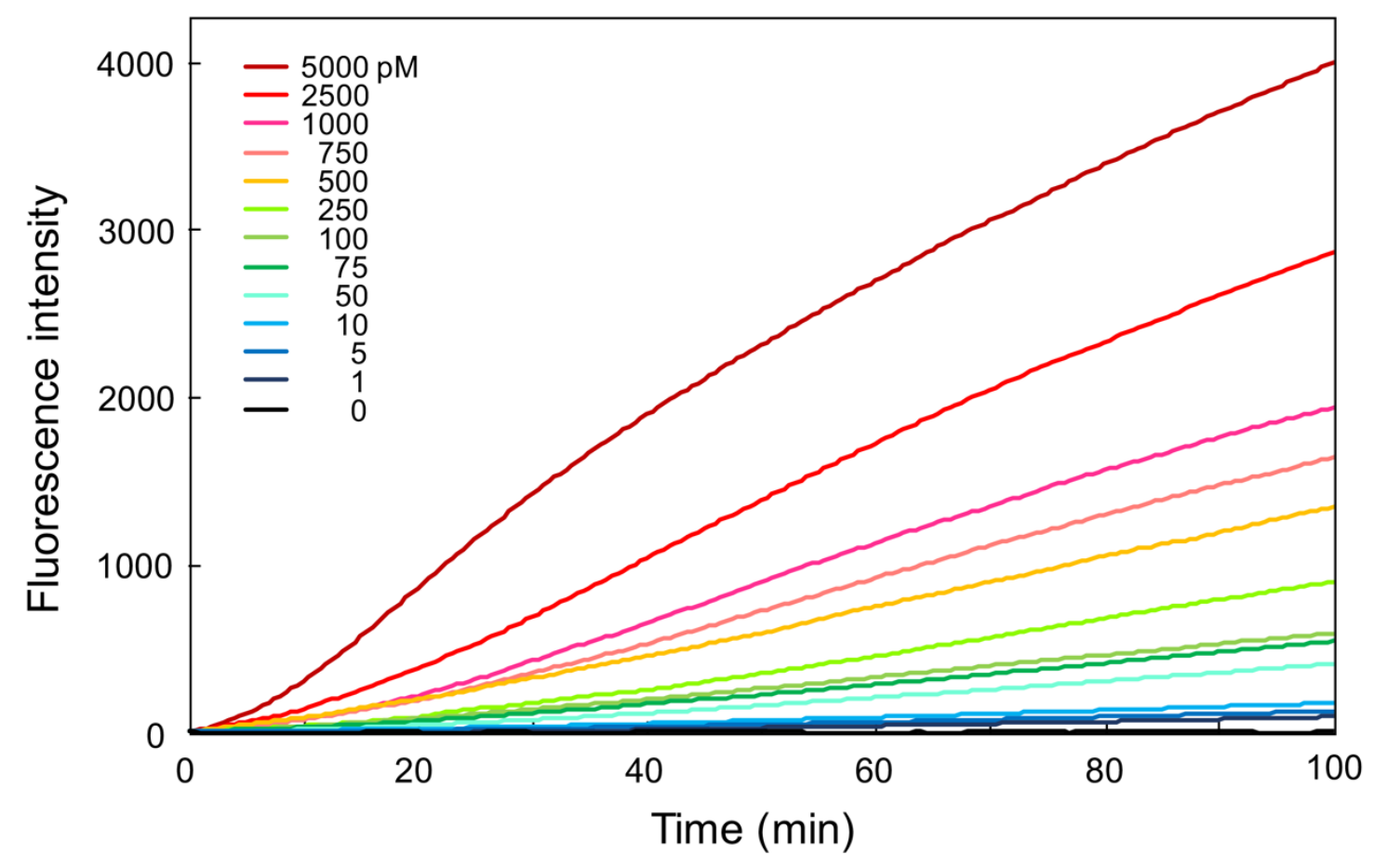

Figure S8. Real-time quantitative analysis by the dual SATIC system: time course of fluorescence intensity of ThT-HE $(5 \mu \mathrm{M})$ with different concentrations of the target RNA, CidR $(0,1,5,10,50,75$, $100,250,500,750,1000,2500$, and $5000 \mathrm{pM})$. 

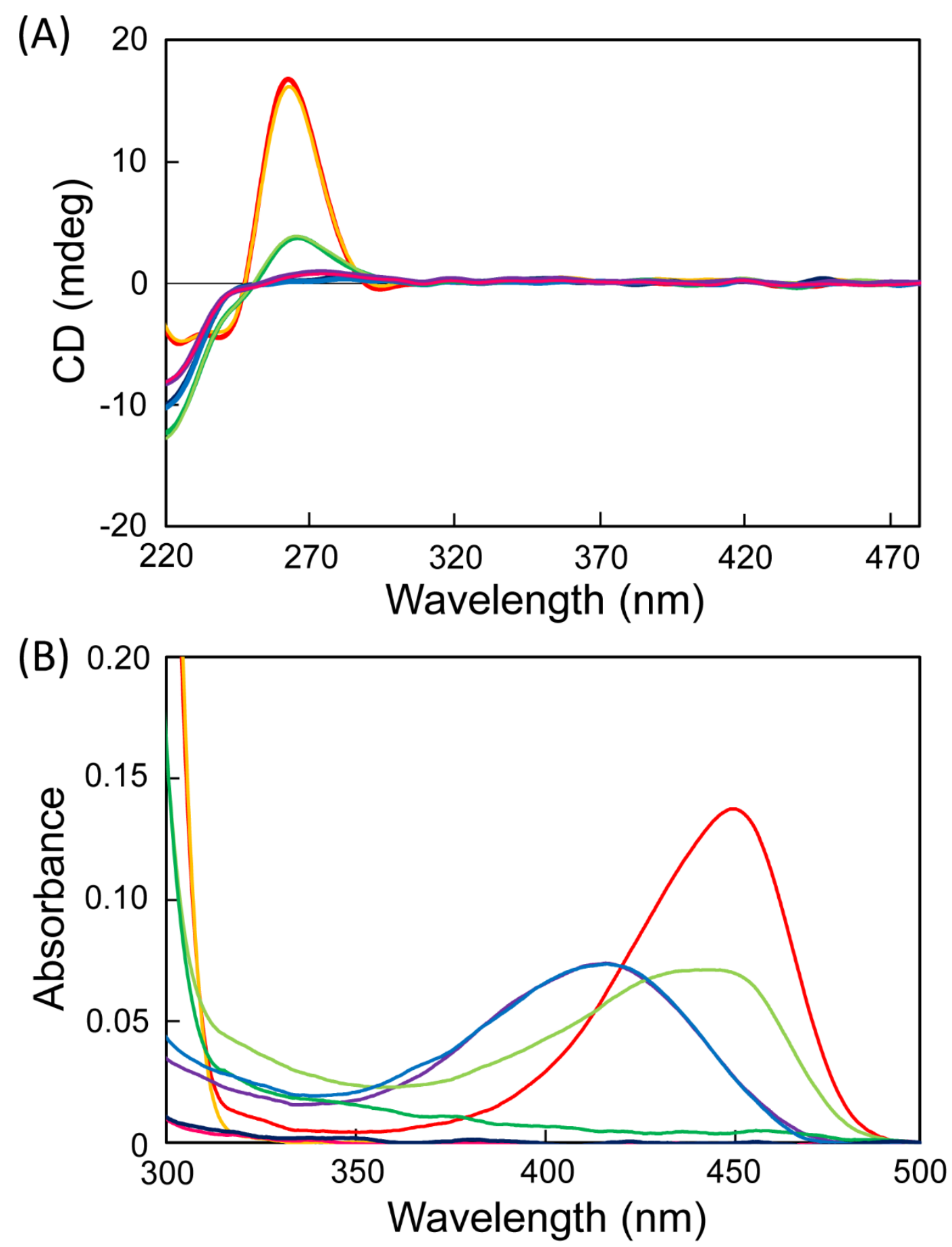

Figure S9. CD spectra (A) and UV-Vis spectra (B) of the reaction mixture of RCA containing primer $\left(\mathrm{P}_{0} \mathrm{~A}\right)$ and template (cT $\left.1 \mathrm{~A}\right)$ with ThT-HE (red) (see Figure S2A), the reaction mixtures of standard SATIC containing the target RNA (CidR) with (yellowish green) and without (green) ThT-HE, reaction mixtures containing the non-target RNA (ArfR) with (purple) and without (pink) ThT-HE, and reaction mixtures free from RNA with (blue) and without (dark blue) ThT-HE. 

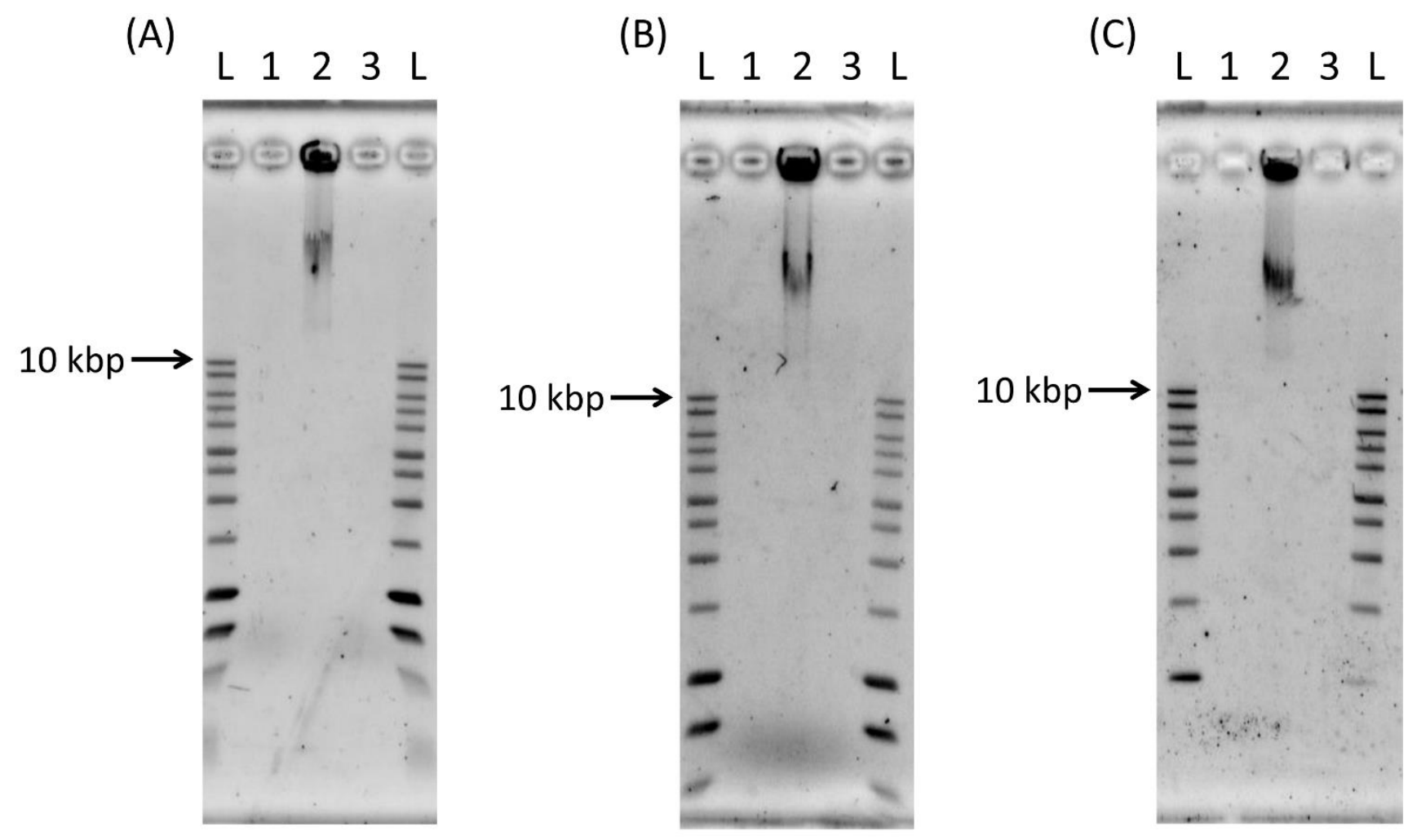

Figure S10. Images of 1\% agarose gel electrophoresis showing (A) products of standard SATIC for the target RNA (CidR), (B) products of dual SATIC for the target RNA (CidR), and (C) products of dual SATIC for the target RNA (miR-21); $10 \mathrm{kbp}$ ladder (lane L), reaction mixture of SATIC free from RNA (lane 1), reaction mixture containing the target RNA, i.e., CidR or miR-21 (lane 2), and reaction mixture containing the non-target RNA, i.e., ArfR instead of CidR or miR-221 instead of miR-21. 
(A)

(B)
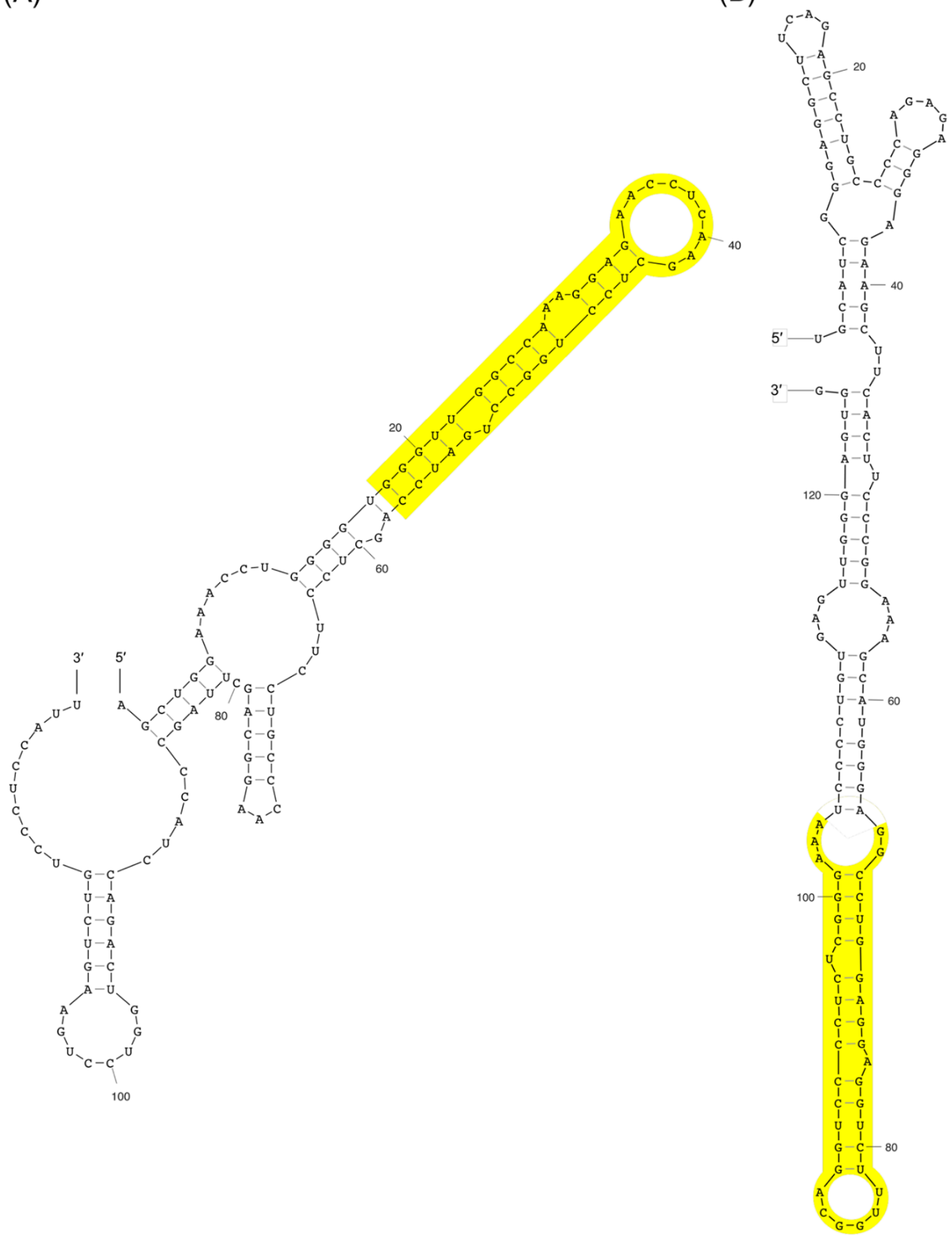

Figure S11. Predicted secondary structures of partial regions of RNA transcripts including the target and non-target RNAs, i.e., (A) CidR and (B) ArfR, respectively, using an mfold-RNA folding form; the sequences of CidR and ArfR are highlighted in yellow. 